tuberculosis allowances to encourage the early diagnosed case to accept treatment.

Undoubtedly the greatest achievement of all was in the field of nutrition. The rationing policy was the result of pre-war research. Long before the War, emergeney food policies had been outlined, and at the outbreak of hostilities the new Ministry of Food accepted as the essentials of its policy not only the need to economize in shipping space but also the equitable distribution of food, with special attention to those on whom the future depended-that is, children and expectant and nursing mothers. Apart from rationing, the raising of the extraction-rate of flour, the development of school milk and meals, and the encouragement of factory canteens were important features of policy.

It is an unexplained wonder that the overcrowding in air-raid shelters produced' so few ill-effects. After the first crisis and blundering of the 'blitz' were over, devoted efforts were directed to the improvement of sanitation and ventilation in the shelters and to the development of medical services and epidemiological studies. All these things must have helped, but they do not explain the providential escape from disease.

Not least among the effects of the 'blitz' was the introduction to each other, through the evacuation, of Disraeli's two nations. The discovery that head lice, impetigo, ringworm and bed-wetting were common was a surprise only because we had shut our eyes to these things in peace-time. In coping with these problems, the School Medical Service played a major part, and it should not be forgotten that the Education Act of 1944, passed in war-time, was an important health act as well as a new policy for education.

In industry, too, there were notable advances. The Factory Department was transferred to the Ministry of Labour and National Service in 1940, and played its part under that Ministry in mitigating the strains of war-time production and black-out conditions. The Factories (Medical and Welfare Services) Order 1940 had its outcome in the spread of medical and nursing services in industry, and in the multiplication of industrial canteens. The Ministry of Supply developed its own industrial medicel service to control the serious toxic hazards in ordnance factories, and with a considerable measure of success.

Not least among the interests of this volume is the story of the health services of the Channel Islands during the German occupation. Finally, as a commentary on Britain in war-time, it is worth recalling that the first planning and negotiations for the National Health Service began early in 1943 when the end of the War was still very far from view.

J. H. F. BRotherstoN

\section{HEALTH AND SAFETY IN AVIATION}

Human Factors in Air Transportation

Occupational Health and Safety. 'By Prof. Ross A. McFarland. Pp. xv +830 . (London : McGraw-Hill Publishing Co., Ltd., 1953.) 106s. $6 d$.

TN an earlier book, "Human Factors in Air Transport Design", Dr. R. A. McFarland, who is professor of industrial hygiene at the Harvard School of Public Health, made an admirably bold and very useful attempt to provide designers of aircraft with information about ways in which they should 'make allowance' for human capacities and inclinations in their aeronautical engineering. In the present book he goes several stages further and offers a multitude of facts and opinions to specialists in aviation medicine, personnel managers, safety experts, and to many more; and, as before, he performs his task in a thoroughly businesslike fashion. Not the least commendable feature of the book is its lucidity. There can be no doubt that from this point of view it will prove an unusually acceptable guide to the layman. Dr. McFarland takes an immense amount of trouble to make himself clear. This shows itself not only in his careful explanation of technical points in ordinary language, but also in his thinking about them (for example, in his use of the substantival, assumption-free term 'accident repeater', on p. 73, for the adjectival, theory-ridden 'accident prone').

The ground he covers is clearly indicated in his well-planned contents pages. After an introductory chapter, which finishes with an assertion of the view that the ultimate success of air transportation will depend on the extent to which the characteristics of its operating and maintenance personnel are understood and the social habits and needs of its pessengers recognized, he goes on to deal with the selection and training of flight personnel and the selection, placing and health of ground personnel. $\mathrm{He}$ ranges widely in these fields and presents a number of useful sum. maries of work done in them, particularly during the Second World War. But sometimes he attempts so much that he lays himself open to a charge of superficiality. Indeed, some of his efforts at condensation lead to rather puzzling statements. For example, on p. 11 he remarks, "Once the tests were found to be of predictive value, the next step was to determine a valid criterion for success in combat". He may perhaps argue that the context made it unnecessary to add the words 'for success in training' after 'predictive value', but surely the saving was scarcely worth while. Again, on p. 75 he appears to fall into the common trap of regarding rating scales as instruments for producing judgments rather than as mere recording devices. Faults of these kinds will not seriously diminish the value of the book to knowledgeable readers, but they may mislead the nonexpert.

Dr. McFarland's chapters on safety on the ground and in flight make good reading, not least because they give him scope for his obvious taste-already displayed in his chapter on the indoctrination and training of flight crews-for formulating plain rules of procedure, securely rooted in careful reflexion on relevant evidence. He seems equally at home in his chapters on sanitation and health in airline operations; but-not unnaturally-he is rather less confident when he comes to examine problems arising in the care of passengers and the trans. portation of patients by air, for in many respects these must be regarded as relatively new. In his final chapter, Dr. McFarland discusses the organization and functions of air-transport medical programmes. So wide and deep is the territory he wants aviation medicine to annex, that a bystander may well wonder where people competent to administer it will be found in the numbers that this immense work will require. But no harm can be done by his thoughtful exposition of his grand ideas. Anyway, it makes a fitting end to a fascinating book.

Alec Rodqer 